\title{
Contribution to the study of kinetic of drying couscous for urban marketing SA
}

\author{
BA Modou, Demba Sow. Samba FAYE, Amy Gassama SOW, Mouhamadou Diop Sall ${ }^{+}$ \\ Laboratoire de Microbiologe Appliquée et de Génie Industriel (MAGI), \\ Ecole Supérieure Polytechnique, Université Cheikh Anta Diop BP 16819 Dakar Fann, Sénégal \\ Corresponding author E-mail : msmdsall@gmail.com
}

\begin{abstract}
The combined effects of the devaluation of the CFA franc in 1992, the food crisis of 2008 and the strong demand for grain products developed urban dwellers have proven to be a necessity of development of grain products manufacturing units marketable and storable without any risk of alteration for cereal craftsmen. This contribution conducted at $40^{\circ} \mathrm{C}$ and $55^{\circ} \mathrm{C}$ with air speeds of $1 \mathrm{~m} / \mathrm{s} 2 \mathrm{~m} / \mathrm{s}$ and $3 \mathrm{~m} / \mathrm{s}$ is in the kinetic study of a technological process couscous drying to determine the optimum conditions of the process of dehydration. She found that the drying kinetics of couscous takes place in three phases; indicating that couscous is rich in water and that it can be stored at room temperature unless it is dried. Henceforth it is imperative to have a good knowledge and mastery of these three phases that impact on product quality This study showed that the experiments performed at a speed of air $3 \mathrm{~m} / \mathrm{s}$ at $40^{\circ} \mathrm{C}$ temperatures and $55^{\circ} \mathrm{C}$, show a brown coloration due to Maillard reactions. We see that the browning phenomena are more pronounced at the speed of $3 \mathrm{~m} / \mathrm{s}$ and $55^{\circ} \mathrm{C}$. It is found that the slow drying is better suited to the quick dry couscous. In addition to further drying the air velocity of $1 \mathrm{~m} / \mathrm{s}$ correlated with the temperature of $40^{\circ} \mathrm{C}$ is the most suitable as well as good monitoring of the evolution of the temperature during the drying phase warm up for a good product.
\end{abstract}

Keywords: kinetics, drying, quality, and Maillard browning reactions

\section{INTRODUCTION}

Cereals are the main food of Senegalese farmers who account for over $60 \%$ of the national population. Since the devaluation of the CFA franc in 1992 and the 2008 food crisis, there is a strong demand for cereal products in urban areas especially the couscous. This sudden resurgence of interest in this once neglected product is due to the reduced purchasing power of citizens and the soaring prices of imported food products. To meet this significant demand, several industry and national artisans have developed couscous production units able to be marketed in urban areas as well as imported products. The fresh couscous is a very perishable product (Krischer O et al., 1963). It must therefore be consumed rapidly or be dried. (Dascalescu A, 1969 and Mafart P,1991) Drying couscous made handcrafted product causes a undesirable color which is a limiting factor for marketing a fortiori for export. This is explained by the non-mastery of drying parameters. This paper aims to study the drying kinetics couscous to determine the optimal conditions of dehydration of the product (Bimbenet JJ, 1984 ; Bimbenet JJ, 2002 and Cheftel JC et al., 1977)

\section{MATERIAL AND METHOD}

\section{Experimental dryer}

We have been operated in a horizontal dryer with a measuring equipment of the different parameters, a heating system by electric resistor, a fan which draws air and pulse on the heating resistors and then the product dry. Several probes placed at different locations are used 


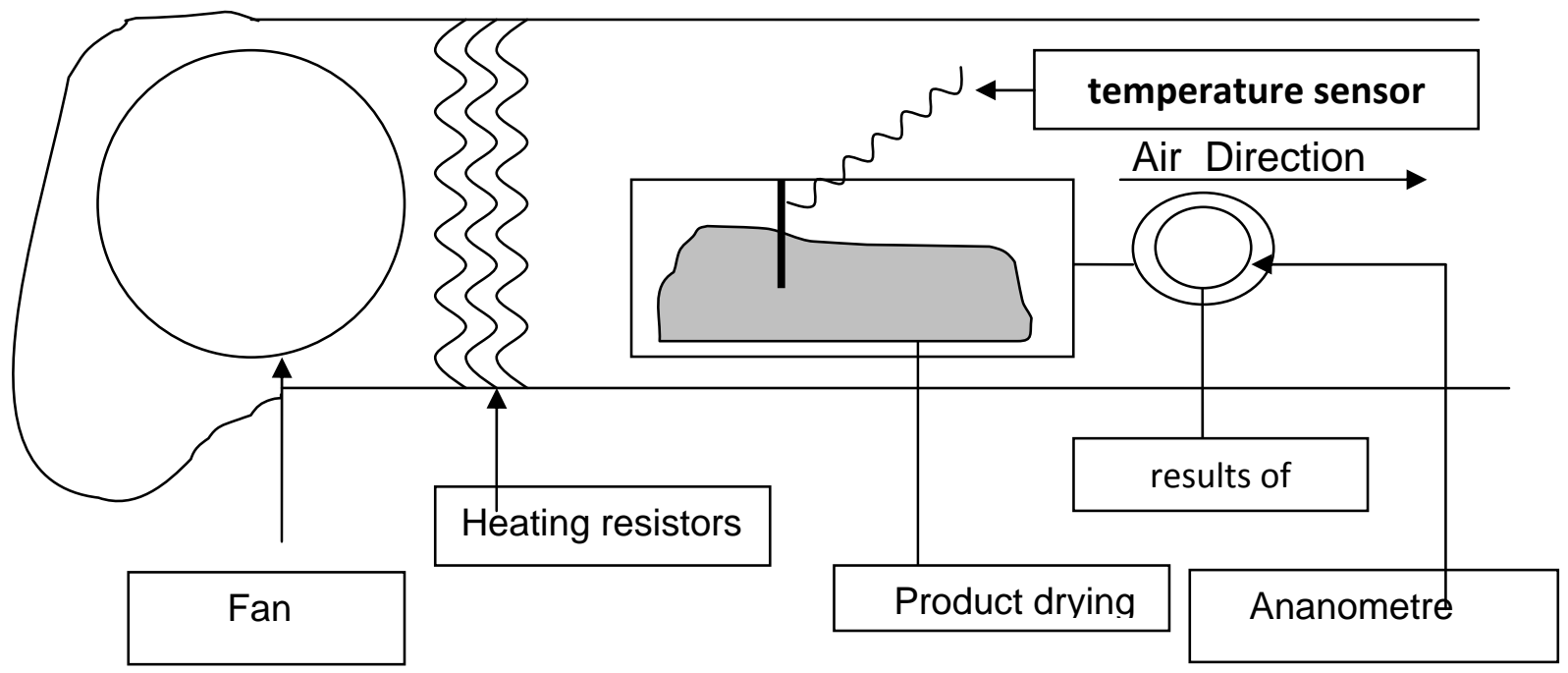

Figure 1. Block diagram of the dryer used

to measure the temperature of the air before and after the product to be dried. (Figure 1). By varying the openings of aspiration of cool air, it controls the flow and the temperature of the drying air during the whole duration of the operation. The product to be dried is placed in a box with a frame made of wood and the side surfaces not tightly woven fabrics. This support allows a good flow of air through the product and hence good drying conditions. A temperature sensor placed the product of the geometric center can monitor the critical temperature of dry couscous. An anemometer placed at the outlet of the dryer to measure the speed of drying air and thus to know the flow rate of the fan knowing the section of the dryer. The humidity of the drying air is measured using a hygrometer placed in hair to the suction area of the fan. To follow the mass loss of the product during drying, we carried the weight measurements every 30 minutes using a precision balance $0,001 \mathrm{~g}$. The end of drying is achieved when the weight is stable. The water activity (aw) is measured with a device called aw meter. The aw values are taken every 55 minutes.

\section{Preparation of product to dry}

The product to be dried (couscous) is prepared in the laboratory with flour obtained from millet seeds hulled millet (souna) ground by conventional mills found in the towns and markets in villages in Senegal (Ba M, 2008). The manufacture of couscous is to wet the flour and then the hand-rolling in order to obtain grains whose dimensions depend on the quality and the desired product. Rolled flour is left open to the air so that the lactic fermentation occurs. The duration of the fermentation depends also on the type of desired product. The rolled and fermented flour is then steamed and the product thus obtained is couscous whose humidity is quite high. It must be consumed quickly or dried if you want to keep it for later use.

\section{RESULTS AND DISCUSSION}

Drying couscous is studied at $40^{\circ} \mathrm{C}$ and $55^{\circ} \mathrm{C}$ with air speeds of $1 \mathrm{~m} / \mathrm{s} 2 \mathrm{~m} / \mathrm{s}$ and $3 \mathrm{~m} / \mathrm{s}$. Couscous moisture loss is monitored as a function of several parameters.

\section{Study of the moisture content of couscous versus time.}

To monitor the mass loss of the product during drying, we conducted weight measurement every 10 minutes and every $20 \mathrm{~min}$ and $30 \mathrm{~min}$.A the end of the operation the curves obtained at $40^{\circ} \mathrm{C}$ and $55^{\circ} \mathrm{C}$ show three phases:

- The first minutes correspond to the first phase which is couscous warm-up;

- The second phase corresponds to the elimination of most of the water;

- The third stage corresponds to the removal of bound water The curve in Figure 2 shows that the first stage lasts 180min for a total drying $510 \mathrm{~min}$. The second phase lasts $120 \mathrm{~min}$. At the end of drying, the water content of the product stabilizes at $11.5 \mathrm{~kg}$ water $/ \mathrm{kg} \mathrm{ms}$ (Ba M, 2008). 
Modou et al. 249

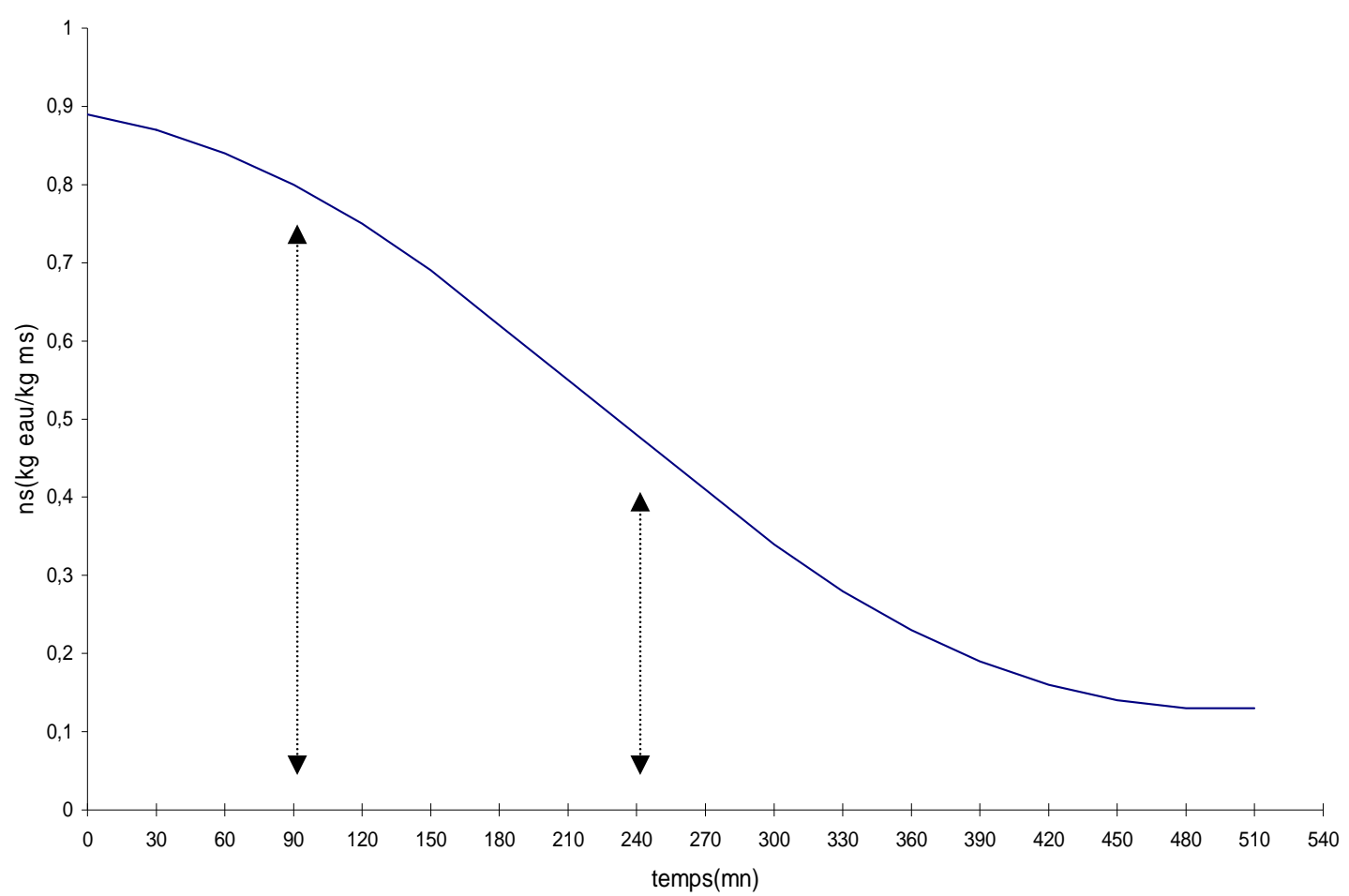

Figure2.Evolution of the couscous water content (ns) as a function of time at. $40^{\circ} \mathrm{C}$ and the air velocity of $1 \mathrm{~m} / \mathrm{s}$

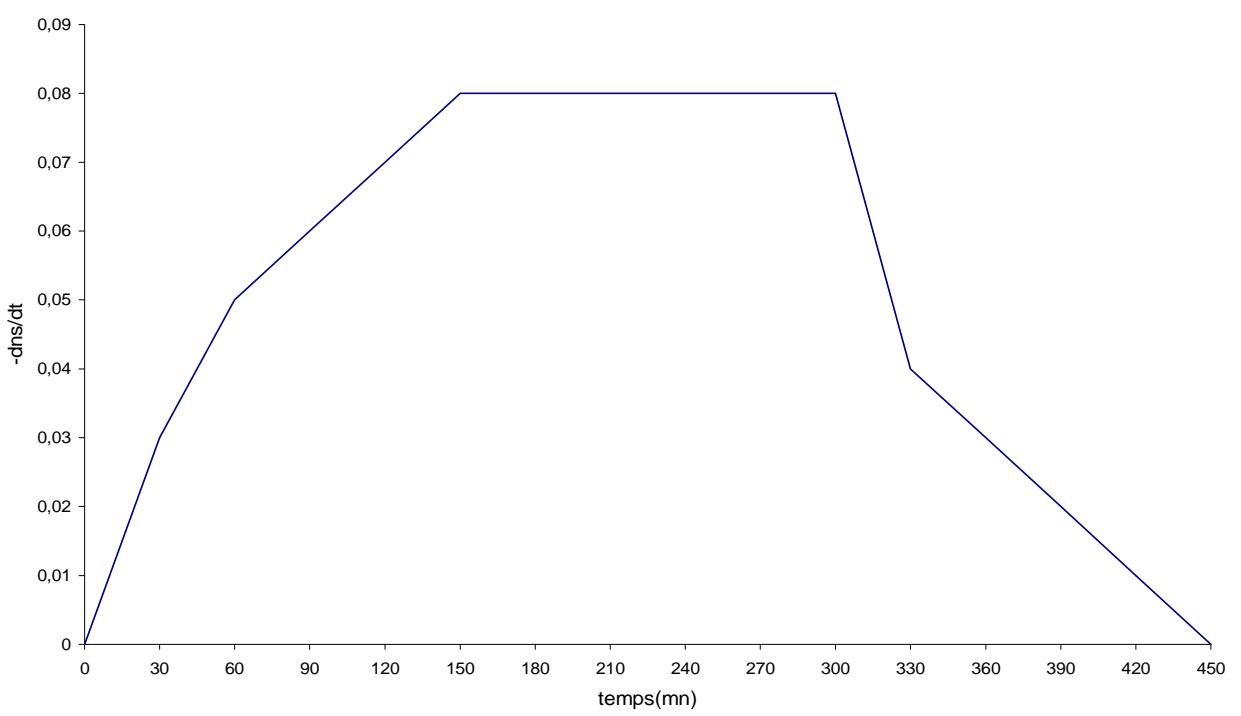

Figure 3. Study of the couscous drying rate as a function of time at $55^{\circ} \mathrm{C}$ and air velocity $1 \mathrm{~m} / \mathrm{s}$

Study of the couscous the drying rate as a function of time.

The curves obtained at 40 and $55^{\circ} \mathrm{C}$ and at 1 drying air velocities, 2 and $3 \mathrm{~m} / \mathrm{s}$ have the same shape. They also show three distinct phases:
-The first phase characterized by increasing speed; -the second phase corresponds to a constant rate of drying;

-a third and final phase is characterized by a decreasing rate of drying. The curve in Figure 3 shows that the drying rate of the first phase fast enough and last long 


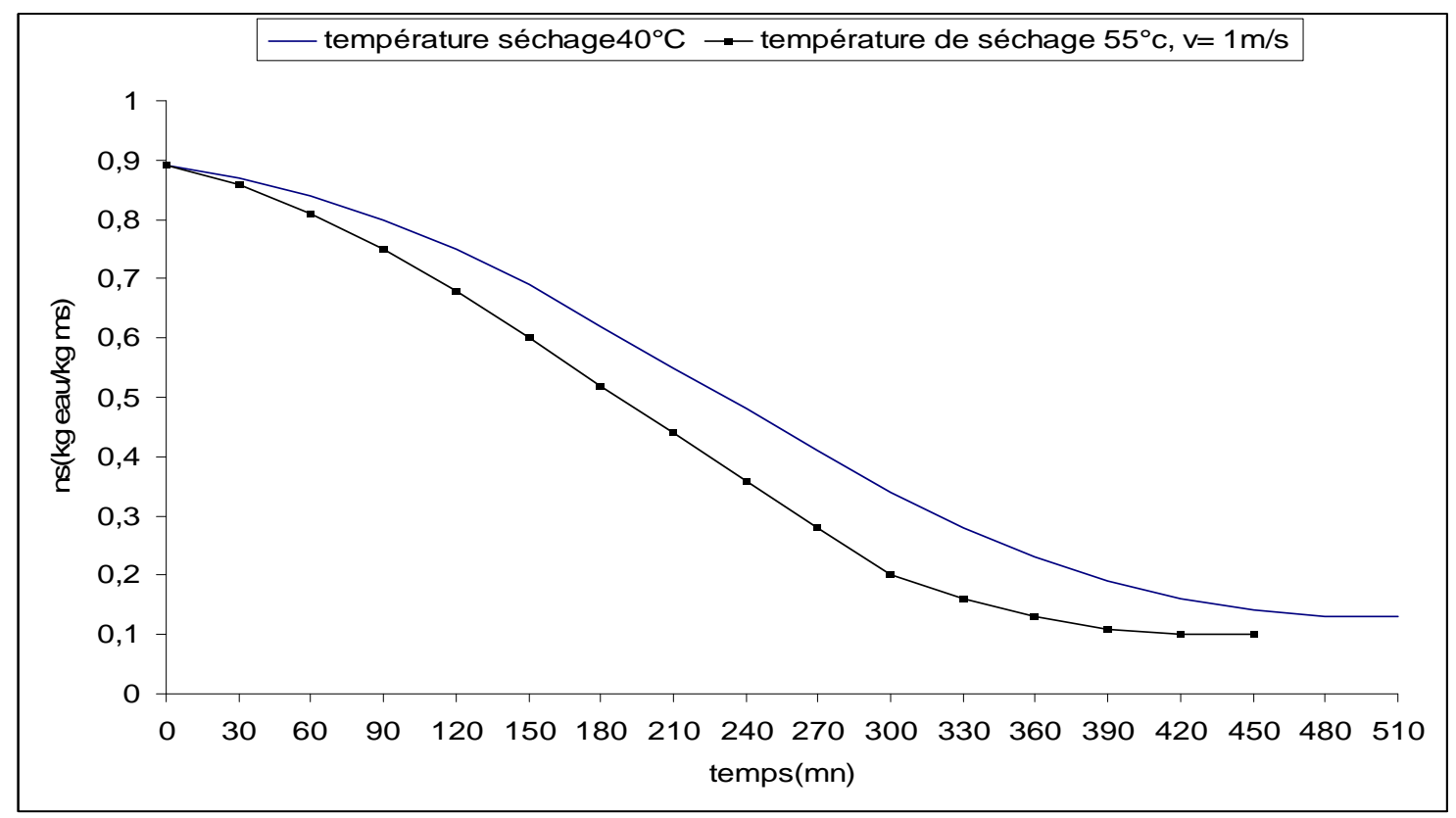

Figure 4. Influence of temperature on the drying time of couscous.

(150min). During the second phase, the drying rate is constant and is at $0.08 \mathrm{~kg}$ of water $/ \mathrm{kg}$ of sèche.min material until the 300th minute. At the beginning of the last phase, there is a rapid decline in the rate of drying.

Influence of temperature on the drying time Temperature plays an important role on the drying time. We note three phases: -The first phase corresponds to the couscous warm-up period; -the second phase at a constant temperature and allows the elimination of free water. -the third couscous where the temperature rises and approaches that of air drying.

(Figure 4) shows that the drying curve at $40^{\circ} \mathrm{C}$ is above that at $55^{\circ} \mathrm{C}$ and their durations are respectively $510 \mathrm{~min}$ and $450 \mathrm{~min}$. 3.4. Influence of the air speed on the drying kinetics of couscous:

Increasing the drying air speed does not significantly change the shape of the couscous drying curves.

The shape of the curves of Figure 5 shows the influence of the air speed on the drying kinetics. The evolution of the curves to $3 \mathrm{~m} / \mathrm{s}$ to $2 \mathrm{~m} / \mathrm{s}$ reached the stage at 150 min, while the curve at $1 \mathrm{~m} / \mathrm{s}$ reaches the address 30 $\min$.

\section{Evolution of the water content of the couscous with time:}

The drying couscous highlights curves whose allure has three phases: warm-up, constant speed and decreasing speed (Figure 2). This pace of couscous drying curves is comparable to that obtained by other authors who have worked on the same product (Clergeand , 1997; GRET, 1988; Krokida MK, 2003 and Mafart P, 1991).

The first phase is the product temperature setting and takes time to stabilize. It corresponds to the change in temperature to the equilibrium temperature displayed by the thermometer wet drying air (GRET, 1988) and in which the amount of water removed is negligible. It is not taken into account in the assessment in determining the water lost from the product and its duration depends on the temperature and the drying air (Clergeand, 1997). The second phase is at a constant speed and moisture eliminated product consists essentially of free water (Krischer O, 1963). This part of the curve is straight and characterizes food products rich in water. During this, the temperature of the product to be dried is constant and corresponds to the wet bulb temperature of the drying air. During this period, the amount of heat transferred by air to the product used exclusively to vaporize the water as couscous lost (Mafart P, 1991). Thus the amount of water removed per unit time is constant and constitutes most of the water removed during drying; it is a period that lasts longer during high temperature drying. The third phase is the drying of the water bound more or less strongly during which the amount of water removed is becoming weaker. Its temperature tends towards that of the drying air and that the product is heated, degrades and undergoes Maillard reactions. Consequently, it must be monitored so that the product temperature does not reach $55^{\circ} \mathrm{C}$ for products where Maillard reactions are undesirable; this is the case couscous. To prevent 
Modou et al. 251

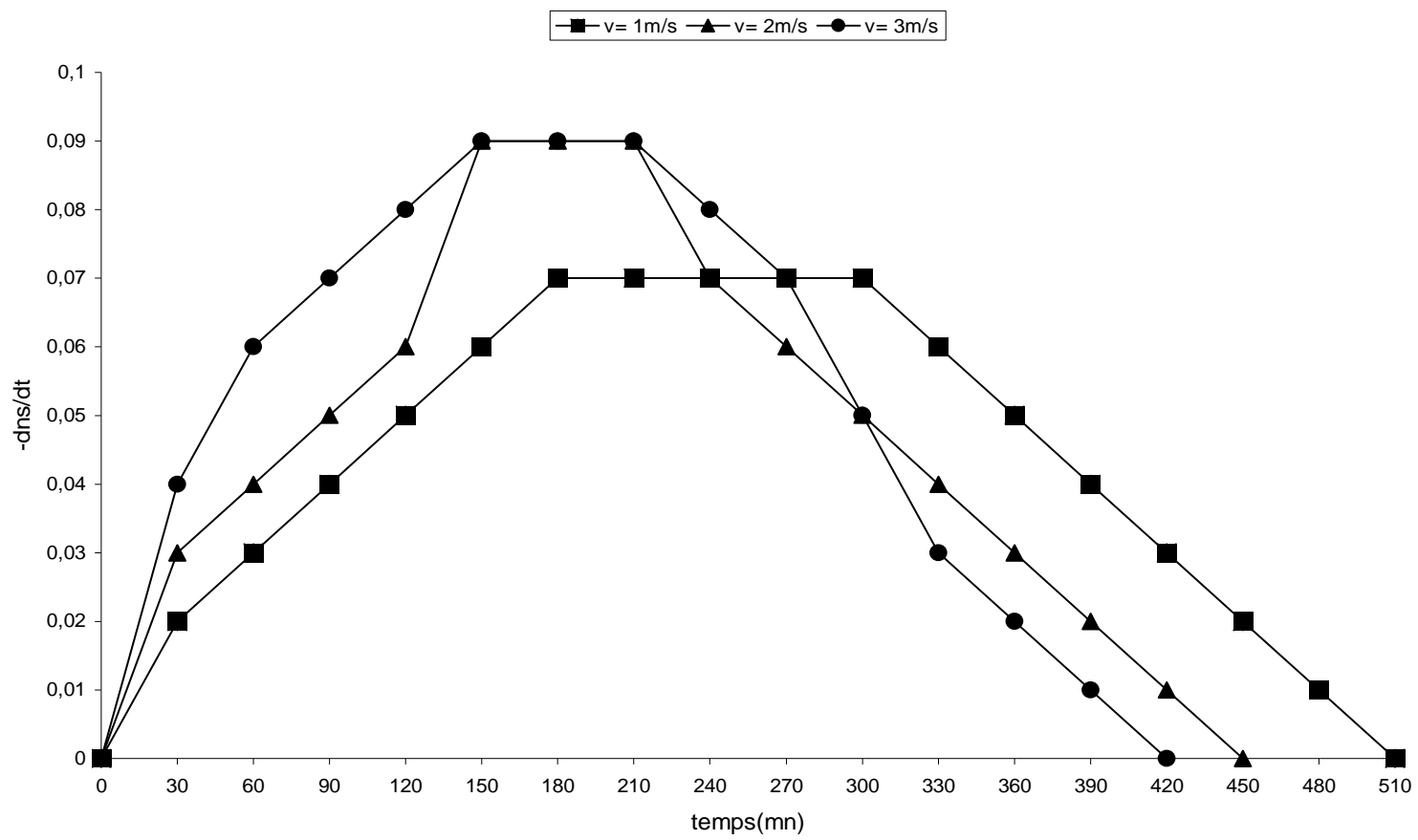

Figure 5 Influence of air velocity on the drying kinetics couscous at $40^{\circ} \mathrm{C}$

Maillard reactions, the product temperature does not reach $55^{\circ} \mathrm{C}$. However, during the drying of certain products other than couscous as organic products including vegetables, several authors (Bimbenet $\mathrm{JJ}$, 1984 ; Bimbenet JJ, 2003; Dumoulin E, 2002; Lasseran JC, 1972 ) reported on the appearance of different curves of us where the first two warm-up phases and constant speed do not appear on the curves but only look to the decreasing phase is observable.

\section{Evolution of the couscous drying speed versus time Couscous}

Drying curves show three phases: the early to critical point (early stage), water that evaporates from the surface of couscous free water. During the warming-up, the speed increases rapidly due to the water vapor pressure gradient between the product and the drying air. The rate of drying during this phase is limited by heat transfer through the boundary layer. The curves appear as a plate (figures 3 ) the duration of which depends on the air speed and drying temperature. Over the drying air rate, the higher this phase is short and a constant quantity of water is removed per unit time. When the couscous surfaces no longer receive free water, the partial pressure of water vapor at the product surface gradually decreases and the drying rate drops more: This is the third phase. The phenomenon that limits the rate of drying is in fact the transfer of water or steam from the interior to the surface of the couscous. This water is in fact linked to the product of the components and its movement through the dry layer is very slow. This step, characterized by a steady decline in the amount of water lost by the product corresponds to an exponential decrease in the rate of drying. To preserve the organoleptic and nutritional qualities of couscous, this step is well followed and arrested in time.

\section{Influence of temperature on couscous drying process:}

According to (Bimbenet JJ, 1984), one can find information on the influence of temperature on drying and its interpretation. (Bimbenet JJ, 1984), and (Lasseran JC, 1972) showed that high temperatures have a significant effect on the drying speed where it is observed that the drying is faster compared to low temperatures. These findings are similar to our results. (Lasseran JC, 1972) relate in their work that acceleration

The drying process due to the increase of the air temperature. This is similar to the results of our work and makes the drying temperature to be a very important factor in the drying rate on the types of products examined. 


\section{Influence of the air speed on the couscous drying kinetics:}

The air speed plays an important role on the one drying kinetics; 2 and $3 \mathrm{~m} / \mathrm{s}$ :

Phase I, air heat used primarily to heat the product, evaporation increases gradually. The kinetics of drying is accelerated to $3 \mathrm{~m} / \mathrm{s}$ (Figure 5).

Phase II, increasing the speed of the drying air to strongly acts on the drying time of the constant speed phase. The bearing of drying speed $3 \mathrm{~m} / \mathrm{s}$ is located 0.11 $\mathrm{g}$ water / $\mathrm{kg} \mathrm{ms} . \mathrm{s}$ and 1 and $2 \mathrm{~m} / \mathrm{s}$ bearings are respectively water to $0.08 \mathrm{~kg} / \mathrm{kg} \mathrm{ms} . \mathrm{s}$ water and $0.10 \mathrm{~kg} /$ $\mathrm{kg} \mathrm{ms} . \mathrm{s}$, this second phase lasts long enough for the drying rate at $1 \mathrm{~m} / \mathrm{s}$ (120 minutes).

During the third phase drying couscous, is removed from the bound water. The water flow is much lower during the second phase of drying. In addition, the air speed has practically no influence on the drying kinetics, as long as it is sufficient to drain water because the migration front then headed to the couscous interior (Kapseu C, 1999 ). Note that the phenomena of browning (Maillard reactions) are accentuated when drying at $3 \mathrm{~m} /$ s. Couscous we dried in the open air at the rate of between 0 to $0.1 \mathrm{~m} / \mathrm{s}$ shows no brown color while the drying couscous the air velocity of $3 \mathrm{~m} / \mathrm{s}$ and temperatures of 40 and $55^{\circ} \mathrm{C}$ shows a brown color which is more accentuated dried at $55^{\circ} \mathrm{C}$ at a rate of $3 \mathrm{~m}$ / s. Couscous drying at $40^{\circ} \mathrm{C}$ and the air velocity of $1 \mathrm{~m} /$ $\mathrm{s}$ gives the best quality of the product ( $\mathrm{Ba} \mathrm{M}$, 2008). These results are consistent with the work (Bimbenet JJ, 1984 and Lasseran JC, 1972)

\section{CONCLUSION}

This work allowed us to show that couscous behaves like most food products. Drying is done in three phases:

- Warm-up phase;

- Constant speed drying phase;

- Heating phase products.

The existence of these phases shows that couscous is rich in water and that it can be stored at room temperature if dried.

The quality of the product from drying depends on the knowledge and mastery of these three phases. It is imperative that the drying is done with proper monitoring of the evolution of the temperature of the products during the couscous warm-up phase.

During this last phase, there is a very rapid rise in temperature which causes degradation couscous and brown color due to Maillard reactions. Drying the last amounts of water to bring the couscous low final moisture content is energetically very costly with negative consequences on the quality of the dried product. However, modulation of the temperature of the hot air is possible depending on the level of drying of the product. While the couscous is drying phase at constant speed, it can withstand high temperatures. At low air speed (slow drying), higher drying temperatures can be used. Thus, drying in the air velocity of $1 \mathrm{~m} / \mathrm{s}$ seems to be better adapted to the temperature of $40^{\circ} \mathrm{C}$.

This study showed that the slow drying is better suited to the couscous fast drying and browning is more pronounced at the speed of $3 \mathrm{~m} / \mathrm{s}$ and $55^{\circ} \mathrm{C}$.

We express our deep gratitude to the Francophone University Agency (AUF) for their support in this work

\section{REFERENCE}

Ba M, (2008).Contribution à l'étude cinétique du séchage du couscous et du arraw et optimisation des procédés. Thèse de Doctorat. Université Cheikh Anta Diop de Dakar. 131 pages.

Bimbenet JJ (1984). Le séchage dans les industries agricoles et alimentaires, Dans les cahiers du Génie Industriel Alimentaire (GIA), Edité par la Sepaic/Paris 2ème édition p 34.

Bimbenet JJ, Duquenoy A, Trystram G (2002).Séchage, cuisson, cuisson-extrusion Dans Génie des Procédés Alimentaires des bases aux applications, Editions RIA-DUNOD- Paris pp 39 1-427 (p554).

Bimbenet JJ, Bonazzi C, Dumoulin E(2002). L'eau en séchage, stockage et réhydratation,

Dans l'eau dans les aliments par LE MESTE M ; LORIENT D. et SIMATOS D ; Edition Tec et Doc. PARIS pp 525-546 (P 674). Burden J et Wills R.B H., 1992, Prévention des pertes après récolte: Fruits, légumes, racines et tubercules, Collection FAO ; formation $N^{\circ} 17 / 2$ Rome.

Charreau A, Cavaille R(1991).Séchage Théorie et calculs, Dans Techniques de Ingénieur, Traité de génie des procédés, J2480 p23.

Cheftel JC, Cheftel H, Besancon $\mathrm{P}(1977)$. Introduction à la biochimie et à la technologie alimentaire vol 1et2.

Clergeand Chantal et Lionel(1997).Les fruits du soleil : Abricot sec, Banane séchée, Châtaigne, Dattes, Figues sèche, Pruneau, Raisin sec, Collection "cuisine et santé" , Edition Equilibre Aujourd'hui.

Colas B (2003)Propriétés structurantes de l'eau dans les légumes et dans les fruits ; influence sur la texture. Dans l'eau dans les aliments par LE MESTE M ; LORIENT D. SIMATOS D ; Edition Tec et Doc Paris p674.

Dascalescu A(1969). Le séchage et ses applications industrielles, Dunod, Paris.

GRET (1988), séchage des produits alimentaires.

Kapseu C, Mapongmetsem PM, Silou T, Roques M(1999).Physicochimie des fruits du safoutier (Dacryodes edulis) camerounais, Tropicultura, 16-17, 37-42.

Krischer $\mathrm{O}$, et Kroell K., (non daté), Techniques du séchage, trad. Française de l'éd. 1963; Centre technique des industries Aérauliques et thermiques, 91402 Orsay.

Krokida MK, Karathanos VT, Maroulis ZB, Marinos KD(2003)Drying kinetics of some vegetables, In journal of food Engineering; 59, 391403.

Lasseran JC(1972).Le séchage du maïs et des autres céréales. BULL.E.F.S (242).

Mafart P(1991).Génie Industriel Alimentaire tome 1, Les procédés physiques de onservation, Edition Lavoisier Tec et Doc, série APRIA, (p295). 